Indexed by

\title{
OPTIMAL THERMAL SENSORS PLACEMENT BASED ON INDOOR THERMAL ENVIRONMENT CHARACTERIZATION BY USING CFD MODEL
}

Crossref
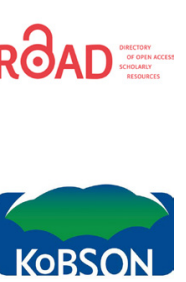

81"Google

\section{Faridah}

Universitas Gadjah Mada, Faculty of Engineering, Department of Nuclear Engineering and Engineering Physics, Yogyakarta, Indonesia

Universitas Gadjah Mada, Graduate School, Doctorate Program in Enviromental Science, Yogyakarta, Indonesia

\section{Sunarno}

Universitas Gadjah Mada, Faculty of Engineering, Department of Nuclear Engineering and Engineering Physics, Yogyakarta, Indonesia

\author{
Sentagi Sesotya Utami \\ Universitas Gadjah Mada, \\ Faculty of Engineering, Depart- \\ ment of Nuclear Engineering \\ and Engineering \\ Physics, Yogyakarta, \\ Indonesia
}

\author{
Ressy Jaya Yanti \\ Universitas Gadjah Mada, \\ Faculty of Engineering, De- \\ partment of Nuclear Engineer- \\ ing and Engineering \\ Physics, Yogyakarta, Indone- \\ sia
}

\author{
Emilya Nurjani \\ Universitas Gadjah Mada, \\ Graduate School, Doctorate \\ Program in Enviromental Sci- \\ ence, Yogyakarta, Indonesia
}

\author{
Rony Wijaya \\ Universitas Gadjah Mada, \\ Faculty of Engineering, De- \\ partment of Nuclear Engineer- \\ ing and Engineering \\ Physics, Yogyakarta, \\ Indonesia
}

Key words: sensor placement, indoor thermal environment, euclidean distance, CFD model, monitoring system doi:10.5937/jaes0-28985

Cite article:

Faridah, Utami, S. S., Yanti, R. J., Sunarno, Nurjani, E., Wijaya, R. (2021), OPTIMAL THERMAL SENSORS PLACEMENT BASED ON INDOOR THERMAL ENVIRONMENT CHARACTERIZATION BY USING CFD MODEL, Journal of Applied Engineering Science, 19(3) 628-641, DOI:10.5937/ jaes0-28985

Online aceess of full paper is available at: www.engineeringscience.rs/browse-issues 


\title{
OPTIMAL THERMAL SENSORS PLACEMENT BASED ON INDOOR THERMAL ENVIRONMENT CHARACTERIZATION BY USING CFD MODEL
}

\author{
Faridah $^{1,2}$, Sentagi Sesotya Utami ${ }^{1 *}$, Ressy Jaya Yanti', Sunarno ${ }^{1}$, Emilya Nurjani $^{2}$, Rony Wijaya ${ }^{1}$ \\ ${ }^{1}$ Universitas Gadjah Mada, Faculty of Engineering, Department of Nuclear Engineering and Engineering \\ Physics, Yogyakarta, Indonesia \\ ${ }^{2}$ Universitas Gadjah Mada, Graduate School, Doctorate Program in Enviromental Science, Yogyakarta, Indonesia
}

This paper discusses an analysis to obtain the optimal thermal sensor placement based on indoor thermal characteristics. The method relies on the Computational Fluid Dynamics (CFD) simulation by manipulating the outdoor climate and indoor air conditioning (AC) system. First, the alternative sensor's position is considered the optimum installation and the occupant's safety. Utilizing the Standardized Euclidean Distance (SED) analysis, these positions are then selected for the best position using the distribution of the thermal parameters' values data at the activity zones. Onsite measurement validated the CFD model results with the maximum root means square error, RMSE, between both data sets as $0.8^{\circ} \mathrm{C}$ for temperature, the relative humidity of $3.5 \%$, and an air velocity of $0.08 \mathrm{~m} / \mathrm{s}$, due to the significant effect of the building location. The Standardized Euclidean Distance (SED) analysis results are the optimum sensor positions that accurately, consistently, and have the optimum \% coverage representing the thermal condition at $1,1 \mathrm{~m}$ floor level. At the optimal positions, actual sensors are installed and proven to be valid results since sensors could detect thermal variables at the height of $1.1 \mathrm{~m}$ with SED validation values of $2.5 \pm 0.3,2.2 \pm 0.6,2.0 \pm 1.1$, for $R 15, R 33$, and $R 40$, respectively.

Key words: sensor placement, indoor thermal environment, euclidean distance, CFD model, monitoring system

\section{INTRODUCTION}

Electricity consumption that meets the thermal comfort demand is currently a strategic issue in the building sector. In Indonesia, energy consumption for the air conditioner (AC) system reached $20-30 \%$ in upper-middle-class residential buildings [1]. Meanwhile, in commercial buildings, $A C$ is estimated to cover more than half of electricity consumption. According to ASHRAE 55 , thermal comfort is a state of mind that describes someone's satisfaction toward the thermal environment, assessed through subjective evaluation [2]. Besides the human factor, thermal comfort is significantly influenced by environmental factors, such as the occupants' thermal environment conditions [3][4]. Every indoor environment has unique thermal environment characteristics that create a unique pattern of its thermal comfort needs. The uniqueness is due to the room's form and orientation, building envelope, outdoor thermal environment, and air conditioning system.

Good building management allows a building to produce an indoor environment with a high thermal comfort level but minimum energy use. A suitable management strategy is obtained by understanding the characteristics of the indoor thermal environment. Therefore, it is essential to have an indoor environment monitoring system. Environmental parameter sensors installed in the indoor environment will provide information that describes the indoor environment's characteristics. Table 1 shows several studies related to the indoor environment monitoring system. The accuracy of the monitoring results depends on the number of sensors installed. More sensors create a more accurate monitoring system representing the indoor environment's characteristics. Hence, Muriel et al. conducted a study in a church where sensors were distributed at several positions of different heights to obtain a detailed distribution of measured environmental parameters at all zones [5]. A similar study was found in [6]. However, the utilization of many sensors would raise the budget and difficulties of its installation, maintenance, and data processing to produce useful information [7].

Measurement errors of the environmental parameters caused by a limited number of sensors can be reduced by optimizing those sensors' placement. Several approaches are found in the previous research used to study sensor placement in indoor environments, aiming to obtain a measurement that could accurately represent the indoor environment's characteristics. Sensor placement, which considers the room's topology, was proposed by T. Seabrook [8] and cited by [9]. The topology strategy was used to place four sensors in 16 rooms in a building optimally and have the minimum number and useful sensors. The building topology was divided into six categories, which are line, star, circle, island, compact-grid, and dispersed-grid. Each of them has a suitable sensor placement location.

Using the thermal parameter values distribution to determine sensor placement can improve the measurement accuracy in representing the indoor environment characteristics. In the case of air quality monitoring systems, the distribution of air quality parameter values can be 
Table 1: Consideration perspective used for sensors' placements in the indoor environment monitoring system

\begin{tabular}{|c|c|c|c|c|c|c|c|}
\hline \multirow{2}{*}{ Ref. } & \multirow{2}{*}{$\begin{array}{c}\text { Authors } \\
\text { (Year) }\end{array}$} & \multicolumn{3}{|c|}{ Thermal comfort parameters } & \multirow{2}{*}{$\begin{array}{c}\text { Visual comfort } \\
\text { parameter } \\
\text { Illumination } \\
\end{array}$} & \multirow{2}{*}{$\begin{array}{c}\text { Air quality } \\
\text { parameter } \\
\text { Contaminant }\end{array}$} & \multirow{2}{*}{$\begin{array}{l}\text { Consideration perspective } \\
\text { for sensors placement }\end{array}$} \\
\hline & & Temperature & Humidity & Air velocity & & & \\
\hline [5] & $\begin{array}{l}\text { Muriel, } \\
\text { M.V.J., et al. } \\
(2014)\end{array}$ & o & o & & & ○ & $\begin{array}{l}\text { Sensors were spread in sev- } \\
\text { eral positions in the building } \\
\text { with different heights. }\end{array}$ \\
\hline [6] & $\begin{array}{l}\text { Rattanong- } \\
\text { phisat, W., } \\
\text { et. Al (2017) }\end{array}$ & o & ० & & & & $\begin{array}{l}\text { Sensors were placed in } \\
\text { several positions in the } \\
\text { building, but there is no fur- } \\
\text { ther detailed explanation. }\end{array}$ \\
\hline $\begin{array}{l}{[8]} \\
{[9]}\end{array}$ & $\begin{array}{l}\text { Seabrook, T } \\
\quad(2016)\end{array}$ & $\circ$ & & & & & $\begin{array}{l}\text { Sensors are placed } \\
\text { based on the room or } \\
\text { building topology. }\end{array}$ \\
\hline [10] & $\begin{array}{c}\text { Eliades, } \\
\text { D.G., (2013) }\end{array}$ & & & & & ० & $\begin{array}{l}\text { The placement of the } \\
\text { sensor is based on the } \\
\text { calculated impact of the } \\
\text { contaminant dispersion } \\
\text { event scenario. }\end{array}$ \\
\hline [11] & $\begin{array}{l}\text { Sharma, H. } \\
\text { (2019) }\end{array}$ & & & & & ० & $\begin{array}{l}\text { The method was based } \\
\text { on the operator move- } \\
\text { ment pattern (transfer op- } \\
\text { erator based framework). }\end{array}$ \\
\hline [12] & $\begin{array}{l}\text { Waeytens, J., } \\
\text { et al. (2018) }\end{array}$ & & & & & ० & $\begin{array}{l}\text { Based on the maximum source } \\
\text { location collected in the room. }\end{array}$ \\
\hline [15] & $\begin{array}{c}\text { Yogana- } \\
\text { than, D. } \\
(2018) \\
\end{array}$ & & & & ○ & & $\begin{array}{l}\text { Sensors placement using } \\
\text { K Means Clustering and } \\
\text { Pareto principal. }\end{array}$ \\
\hline [14] & $\begin{array}{l}\text { Lee, S., et } \\
\text { al. (2019) }\end{array}$ & ○ & & & & & $\begin{array}{l}\text { Sensor placement is based } \\
\text { on errors and entropy of } \\
\text { the measurement results. }\end{array}$ \\
\hline [16] & $\begin{array}{l}\text { Erickson, P., } \\
\text { et al. (2015) }\end{array}$ & ○ & $\circ$ & & & & $\begin{array}{l}\text { Sensor placement is based } \\
\text { on the Gaussian process. }\end{array}$ \\
\hline [17] & $\begin{array}{l}\text { Al-Kuwari, } \\
\text { M., et al. } \\
(2018)\end{array}$ & o & ○ & & o & $\circ$ & $\begin{array}{c}\text { Sensors were placed inside } \\
\text { the room, particularly under } \\
\text { the ceiling. }\end{array}$ \\
\hline [18] & $\begin{array}{l}\text { Zhou, P., et } \\
\text { al. I (2015) }\end{array}$ & o & & & & & $\begin{array}{l}\text { Sensors were placed at } \\
\text { the height of } 2 \mathrm{~m} \text { for safety } \\
\text { and to prevent interfer- } \\
\text { ence from its occupants. }\end{array}$ \\
\hline [19] & $\begin{array}{l}\text { Jin, Y., et al. } \\
\text { (2018) }\end{array}$ & $\circ$ & o & o & & & $\begin{array}{l}\text { Sensors were placed at the } \\
\text { height of } 1.6 \mathrm{~m} \text { (represent- } \\
\text { ing the environment around } \\
\text { the occupant's neck). }\end{array}$ \\
\hline [13] & $\begin{array}{l}\text { Yanti., R. J., } \\
\text { et al. (2019) }\end{array}$ & o & & & & & $\begin{array}{l}\text { Sensor placement is based } \\
\text { on the Gaussian process } \\
\text { analysis in variable values } \\
\text { distribution at the height of } \\
1.1 \mathrm{~m} \text { using CFD simulation. }\end{array}$ \\
\hline & This paper & ○ & ० & ○ & & & $\begin{array}{l}\text { Sensors placement based } \\
\text { on analysis of Standardized } \\
\text { Euclidean Distance in variable } \\
\text { values distribution at the height } \\
\text { of } 1.1 \mathrm{~m} \text { using CFD simulation } \\
\text { for several scenarios. }\end{array}$ \\
\hline
\end{tabular}


traced using contaminant dispersion scenarios [10], operator displacement patterns [11], and CFD simulations to localize the maximum source [12]. Meanwhile, in a thermal environment monitoring system, the thermal environment parameter value distribution can be obtained using CFD simulations, as done in [13].

Several methods could be used to analyze the environment parameters' value distribution. One can obtain the sensors' locations to provide the most accurate measured values, such as the calculation of errors and entropy of the measurement results [14], K-Means Clustering [15], and Gaussian process [16].

Another essential consideration is the occupants' activities. The installed sensors should not interfere with the occupants' activities, such as placing the sensors on the ceiling [17] or at the height of $2 \mathrm{~m}$ [18]. Hence, occupant activities' type and location will determine the number of sensors and their location. The value measured by the sensor is the value of the environmental parameter perceived by the occupants. Jin, Y. et al. [19] used a sensor at the height of $1.6 \mathrm{~m}$ on a thermal environment monitoring system in a city residence in China that represents the environment around the occupation's neck when performing an activity while standing.

Yanti, R. J., et al. [13] considered the thermal parameters value distribution at a height determined by its occupant activity in an educational building classroom. The students carried out studying activities while sitting and feeling the exposure to thermal conditions at the height of $1.1 \mathrm{~m}$ [2]. The data was obtained from a CFD simulation using IESVE software. Meanwhile, the method used to determine the sensor location from the distribution data is the Gaussian method. The study is limited in its value distribution data of the indoor thermal environment parameter, representing one thermal parameter and one room condition scenario. A condition that is not quite enough to describe the indoor thermal environment in the reviewed case. Furthermore, validation of the analysis results on the installed sensor is not yet discussed.

Given the discussion above, it can be assured that a method for finding the optimal thermal sensor placement is not yet available. Hence, the sensors data should obtain indoor thermal characteristics on the occupant's activity using three thermal parameters: temperature, relative humidity, and air velocity.

This paper discusses an analysis of optimal sensor placement positions by considering indoor thermal characteristics on the occupant's activity area. The indoor thermal environment characteristics are obtained from the data distribution of the thermal environment parameters value for several possible room conditions using CFD simulation by manipulating the outdoor climate and air conditioning system. The alternative sensors' positions are determined by considering installation convenience and occupant's safety. Utilizing the Standardized Euclidean Distance analysis, these positions are then selected for the best position using the distribution of the thermal parameters' values data at the activity zones. This method was chosen since it can present three dimensions of thermal environment parameters measurement, including temperature, humidity, and air velocity [20].

\section{MATERIALS AND METHODS}

The methodology used in this research consists of 3 stages: field observation, simulation of indoor thermal environment condition scenario using the CFD model, and sensors placement analysis, as shown in Figure 1. It will be further explained in the next section.

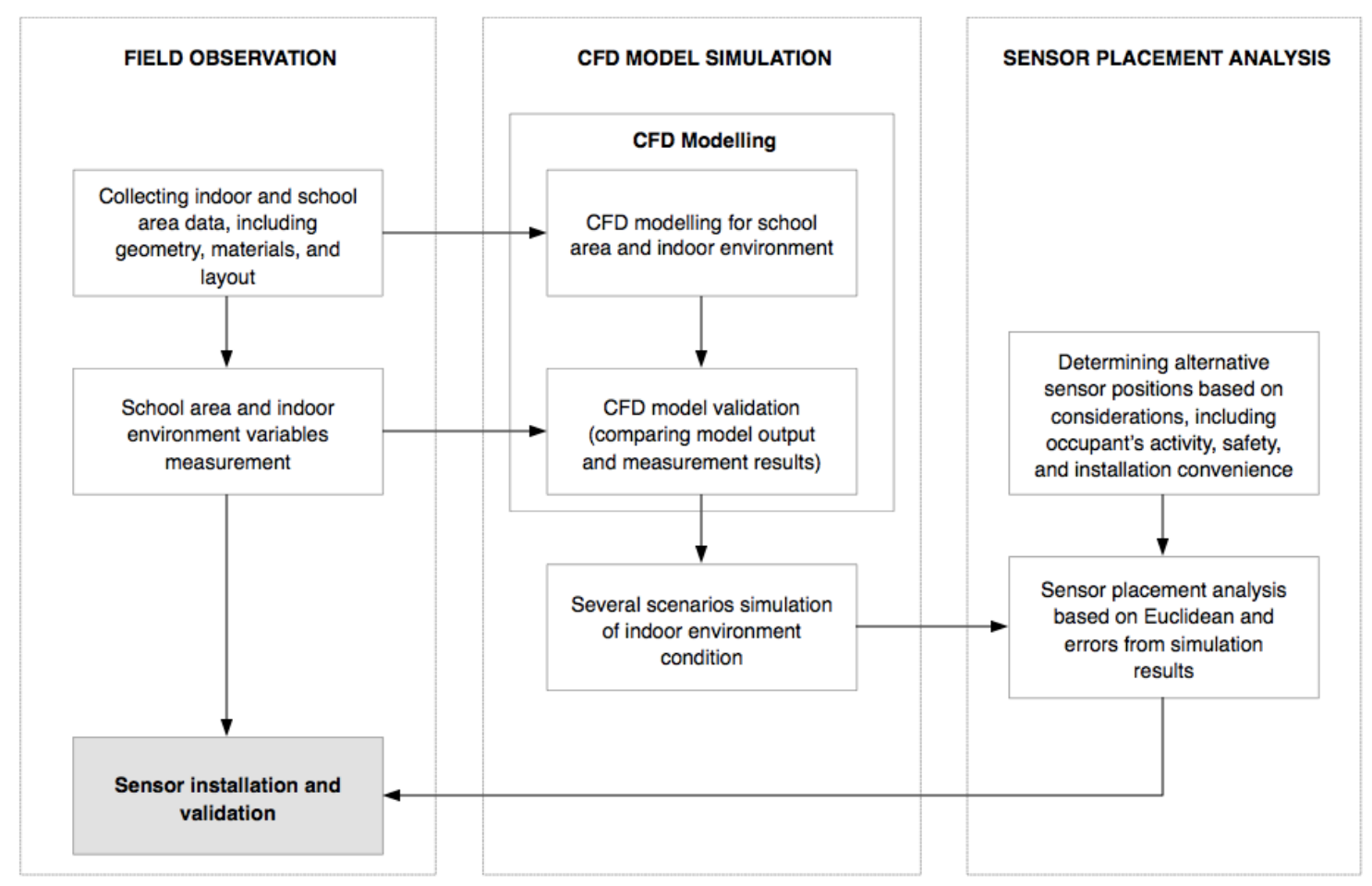

Figure 1: The methodology of research 


\section{Study case}

The case studied in this research is an educational building room in SMKN 3 Yogyakarta, a vocational high school located in Yogyakarta, Indonesia, with $30,000 \mathrm{~m}^{2}$ (Figure 2). Its buildings consist of old buildings with Yogyakarta-local design and new buildings with modern design. Generally, a classroom's geometry is typical with the same form and envelope. The air conditioning systems vary, but most of the classroom still use natural ventilation.

The three classrooms observed are R15, R33, and R40 classrooms (Figure $2 b$ ), which have typical materials and envelopes. R15 classroom's dimension is $15 \times 9 \mathrm{~m}^{2}$ with three Air Conditioners; meanwhile, R33 and R40 dimensions are $9 \times 9 m^{2}$ with natural ventilation. Their geometry is shown in Figure 3.

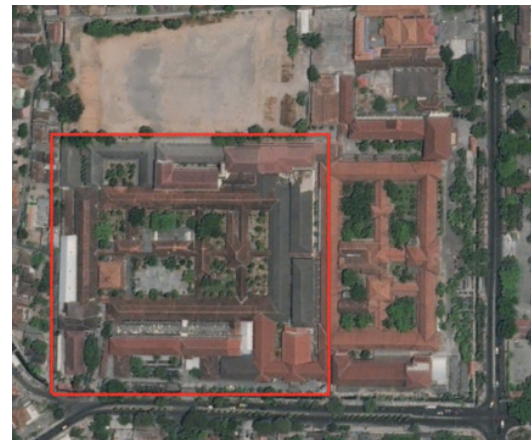

(a)

\section{CFD modeling}

The indoor thermal environment's characterization was conducted by analyzing the thermal environment parameters value for several possible room conditions using the CFD model results by manipulating the outdoor climate and air conditioning system. One of the essential factors in CFD modeling for the indoor thermal environment is the school area where rooms or buildings exist. The closer it is to the ground, where most of the living things are, the more the atmosphere's elements change rapidly. For example, the wind velocity will decrease as it gets closer to the ground due to friction and less air mixture. The climate in the land surface, called microclimate, is vertically estimated up to $1.5-2 \mathrm{~m}$ [21]. The main factors that influence microclimate are land surface conditions,

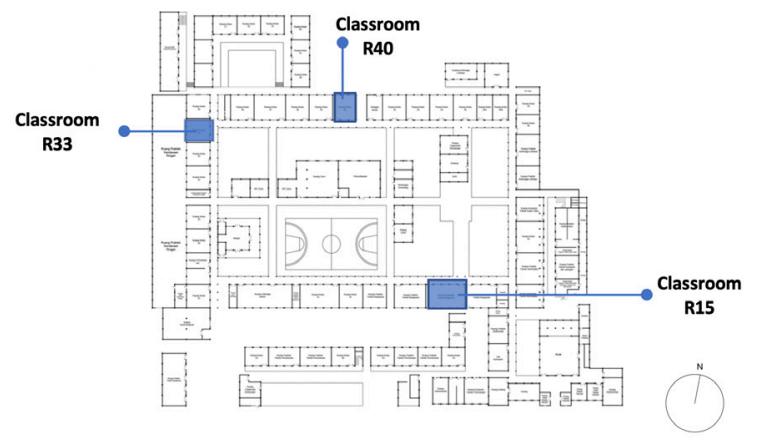

(b)

Figure 2: School area, (a), and rooms layout, (b), of SMKN 3 Yogyakarta
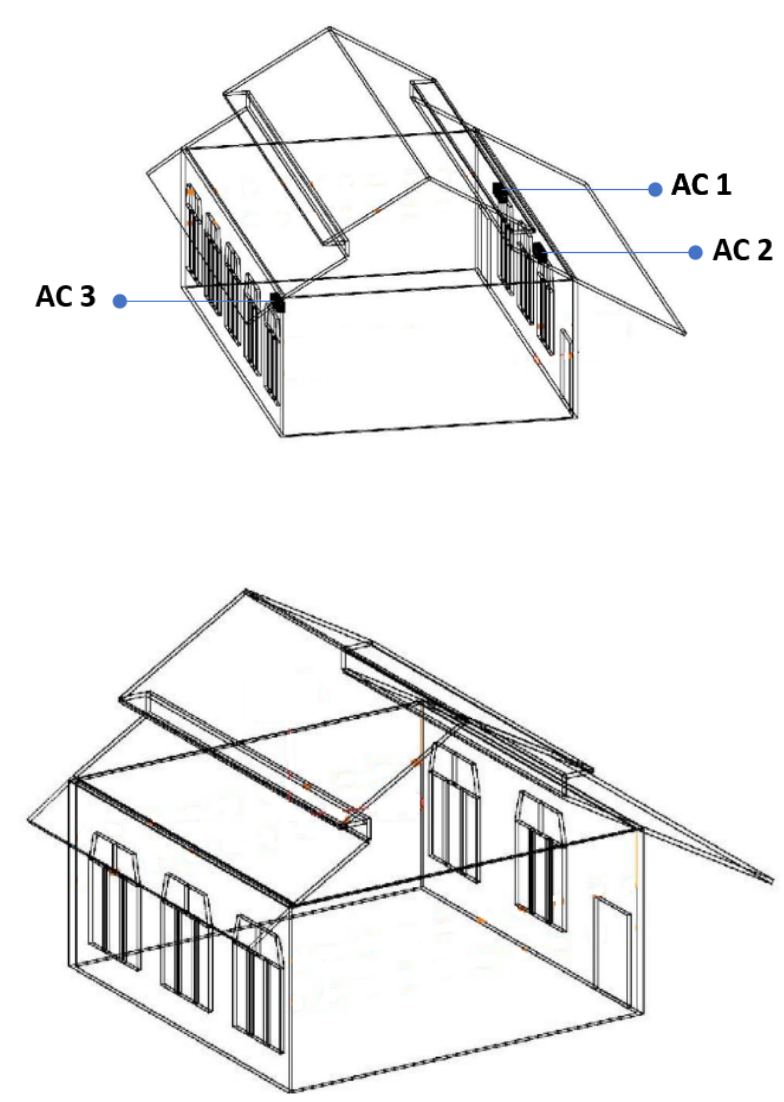

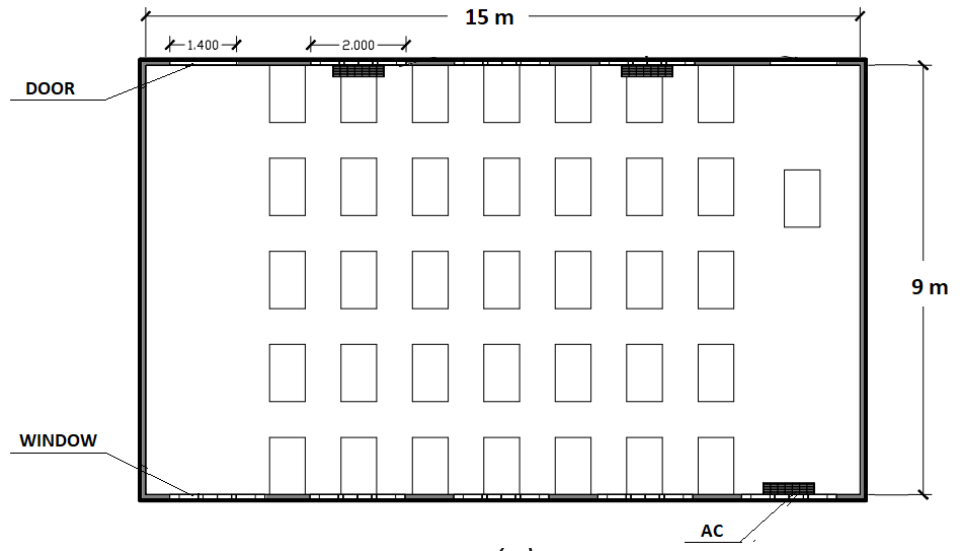

(a)

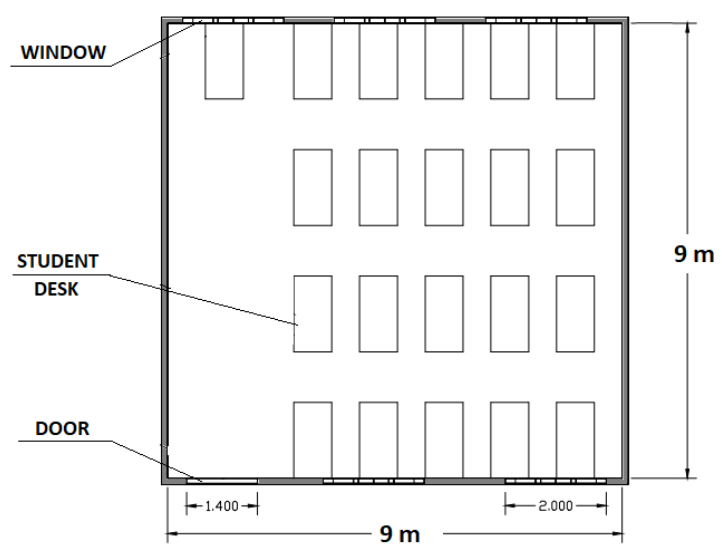

(b)

Figure 3: The geometry of (a) R15, (b) R33 and R40 
which includes soil, vegetation, and building infrastructures. These factors will affect the amount of solar radiation energy received and reflected on the surface and the air movement on the land surface. For an indoor environment with fixed form, orientation, envelope, function, and occupants, the indoor thermal environment would be influenced by microclimate and air conditioning systems. In this research, the indoor environment that consists of $\mathrm{R} 15, \mathrm{R} 33$, and R40 classrooms were modeled into the SMKN 3 Yogyakarta school area. The CFD model was built in software called Integrated Environmental Solution - Virtual Environment (IES-VE). IES-VE is a commercial software to perform a comprehensive building simulation needed by professionals to conduct a detailed environmental assessment and optimize building design [22] [23]. Three essential tools in IES-VE used to perform CFD simulation for gaining value distribution of indoor thermal environment parameters are ApacheSim, Microflow, and Suncast. ApacheSim is a dynamic thermal simulation program based on the mathematical model of heat transfer. Simulation in ApacheSim resulted in a resultant value of indoor thermal environment conditions that will change dynamically due to the alteration of disturbance from time to time. Microflow simulation is used to obtain the value distribution of indoor environment pa- rameters at certain heights, which requires CFD simulation. Meanwhile, Suncast is utilized to gain the irradiation flux value on the building envelope surface. Table 2 is the list of IES-VE settings used in the CFD modelling.

CFD simulation is a numerical solution related to three fluid flow conservation equations, including continuity, momentum, and energy conservation [24]. CFD model's quality can be shown from the convergence test and mass balance test. The convergence test is performed by reviewing the residual value that indicates an imbalance from the conservation equation. Meanwhile, the mass balance test is conducted to ensure if the system satisfies the mass conservation law in which the mass flow entering the system through an inlet should equal the mass flow leaving through an outlet.

Model validation was done by comparing the model results in IES-VE with field measurement. For the school area thermal environment model, the irradiation flux variable is represented by the building envelope's temperature [25]. Measurement of the building envelope temperature used a thermal camera on the R15, R33, and R40 classrooms' wall surfaces. Meanwhile, wind velocity measurement was done in several locations in the school area and measured at the height of $1.5 \mathrm{~m}$ and $3 \mathrm{~m}$. Model validation of the indoor thermal environment was

Table 2: IES-VE setting in CFD modeling

\begin{tabular}{|l|l|}
\hline Input & Yogyakarta (file .epw from meteonorm) \\
\hline Weather data & \multicolumn{2}{|l|}{} \\
\hline Parameter Model & $: 0.2585 \mathrm{~W} / \mathrm{m}^{2} \mathrm{~K}$ \\
\hline Roat transfer coefficient & $: 2.4910 \mathrm{~W} / \mathrm{m}^{2} \mathrm{~K}$ \\
Internal wall (plaster-brick-plaster) & $: 3.078 \mathrm{~W} / \mathrm{m}^{2} \mathrm{~K}$ \\
External wall (plaster-brick-plaster) & $: 2.2967 \mathrm{~W} / \mathrm{m}^{2} \mathrm{~K}$ \\
Door & \\
Floor & $: 0.6518 \mathrm{~W} / \mathrm{m}^{2} \mathrm{~K}$ \\
R15 (concrete tiles - synthetic carpet) & $: 0.8949 \mathrm{~W} / \mathrm{m}^{2} \mathrm{~K}$ \\
R33-R40 (concrete tiles) & $: 3.8502 \mathrm{~W} / \mathrm{m}^{2} \mathrm{~K}$ \\
Grille ventilation & $: 6.3962 \mathrm{~W} / \mathrm{m}^{2} \mathrm{~K}$ \\
\hline Clear glass window & $3 \mathrm{D}$ \\
\hline Room geometry & \\
\hline Location & $6.97^{\circ}$ South \\
\hline Latitude & $110.37^{\circ}$ East \\
\hline Longitude & $113 \mathrm{~m}$ \\
\hline Elevation & Normal \\
\hline Wind exposure & Suburbs \\
\hline Terrains type & Top hung \\
\hline Window & Side hung \\
\hline Door & \\
\hline Output & $:$ Wind velocity, Irradiation flux \\
\hline School area thermal environment & $:$ Temperature, Relative humidity, Air velocity \\
\hline Indoor thermal environment &
\end{tabular}


conducted for the model output variables, including air temperature, humidity, and air velocity. Those three variables measurement was done in 5 measurement points inside the classrooms at the height of $1 \mathrm{~m}, 2 \mathrm{~m}$, and $3 \mathrm{~m}$.

\section{Simulation of thermal environment condition scenario}

The thermal environment model's simulation aims to obtain the distribution of thermal environment parameter values data on occupants living zones. In our model, students as occupants are doing learning activities in a classroom while experiencing thermal conditions at the height of $1.1 \mathrm{~m}$ [2]. Several input scenarios are given to obtain simulation results representing the characteristics of the indoor thermal environment. Table 3 shows the outdoor climate and air conditioning input scenarios by varying the IES-VE weather data settings. The four different dates represent the sun's annual path from the equator towards $23.5^{\circ} \mathrm{N}$ and $23.5^{\circ} \mathrm{S}$.

\section{Sensors placement analysis}

Two steps of approaches are used to determine thermal sensor locations. First, the method is considered an alternative position where the sensor installation is convenient and ensures the occupant's safety. Secondly, the sensor locations were decided by representing the indoor thermal environment (temperature, humidity, and air velocity) at the height of $1.1 \mathrm{~m}$. The representation level is described by the Euclidean distance between the installed sensor measured value and the thermal condition measurement value at the height of $1.1 \mathrm{~m}$, as shown in Figure 4.

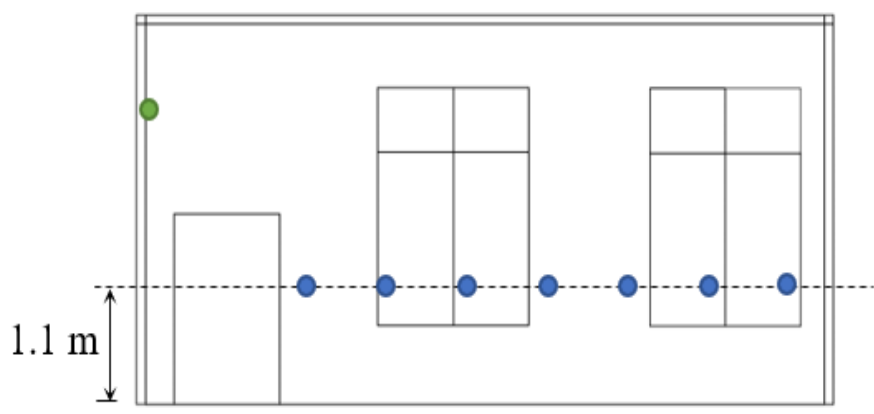

Figure 4: Sensors and the represented thermal condition positions

The Euclidean distance is the conventional distance measurement commonly used for data classification due to its simplicity and applications. If there are two vectors of $j$-dimension, namely $x$ and $y$, the Euclidean distance, $d_{x, y}$, between these two vectors can be formulated,

$d_{x, y}=\sqrt{\sum_{j=1}^{J}\left(x_{j}-y_{j}\right)^{2}}$

Equation (1) is used to obtain the representation level of the thermal conditions at the height of $1.1 \mathrm{~m}, x$, with the results of sensor measurement at the alternative position, $y$, for three dimensions of thermal condition measurement, including air temperature, $t_{a}$, humidity, $R H$, and air velocity, $v_{a}$, in the indoor environment. Thus, resulted in Equation (2),

$d_{x, y}=\sqrt{\left(x_{j}-y_{j}\right)^{2}+\left(x_{R H}-y_{R H}\right)^{2}+\left(x_{v_{s}}-y_{v_{a}}\right)^{2}}$

A problem would arise because the measurement's three dimensions are three different variables with three different units. Therefore, a data transformation is required to

Table 3: Input variables variation in CFD model simulation of the school area and indoor environment

\begin{tabular}{|c|c|c|c|}
\hline \multirow{2}{*}{ Classroom } & \multicolumn{2}{|c|}{ Model input variable } & \multirow{2}{*}{ Output Variable } \\
\hline & Building outdoor climate & Indoor air conditioning & \\
\hline $\begin{array}{l}\text { R15 Classroom } \\
\text { (16 scenarios) }\end{array}$ & $\begin{array}{l}\text { Weather data date setting } \\
\text { on: } \\
\text { M-21 March } \\
\text { J-21 June } \\
\text { S-23 September } \\
\text { D-22 December }\end{array}$ & $\begin{array}{c}\text { AC ON/OFF: } \\
\text { AC OFF } \\
\text { AC0-1 AC ON } \\
\text { AC2-2 AC ON } \\
\text { AC3-3 AC ON }\end{array}$ & $\begin{array}{l}\text { School area thermal environment } \\
\text { parameters: }\end{array}$ \\
\hline $\begin{array}{l}\text { R33 Classroom } \\
\text { (12 scenarios) }\end{array}$ & $\begin{array}{l}\text { Weather data date setting } \\
\text { on: } \\
\text { M-21 March } \\
\text { J-21 June } \\
\text { S-23 September } \\
\text { D-22 December }\end{array}$ & $\begin{array}{l}\text { Window Opening } \\
\text { J0-Closed } \\
\text { J1-Opened } \\
\text { Door Opening } \\
\text { J0-Closed } \\
\text { J1-Opened }\end{array}$ & $\begin{array}{l}\text { Distribution of solar flux irra- } \\
\text { diation on classroom external } \\
\text { envelope. } \\
\text { - Wind velocity distribution at } \\
\text { the height of } 1.5 \mathrm{~m} \text {. } \\
\text { Indoor thermal environment pa- } \\
\text { rameters: }\end{array}$ \\
\hline $\begin{array}{l}\text { R40 Classroom } \\
\text { (12 scenarios) }\end{array}$ & $\begin{array}{l}\text { Weather data date setting } \\
\text { on: } \\
\qquad \begin{array}{c}\text { M-21 March } \\
\text { J-21 June } \\
\text { S-23 September } \\
\text { D-22 December }\end{array}\end{array}$ & $\begin{array}{l}\text { Window Opening } \\
\text { J0-Closed } \\
\text { J1-Opened } \\
\text { Door Opening } \\
\text { J0-Closed } \\
\text { J1-Opened }\end{array}$ & $\begin{array}{l}\text { Distribution of temperature, humid- } \\
\text { ity, and air velocity at the height of } \\
1.1 \mathrm{~m} .\end{array}$ \\
\hline
\end{tabular}


balance the data distribution. One of the easiest ways is making variants from the three distributions equal to 1 , and placing the distribution center in the mean value equals 0 . The data transformation will produce a standardized value [20],

$$
\text { standardized value }=\frac{\text { original value }- \text { mean value }}{\text { standard deviation }}
$$

Thus, Equation (2) could be written into Standardized Euclidean Distance (SED),

$$
d_{x, y}=\sqrt{\left(\frac{x_{t_{a}}-y_{t_{a}}}{S_{t_{a}}}\right)^{2}+\left(\frac{x_{R H}-y_{R H}}{S_{R H}}\right)^{2}+\left(\frac{x_{v_{a}}-y_{v_{a}}}{S_{v_{a}}}\right)^{2}}
$$

Where $S$ is the standard deviation calculated for all data in each dimension or measurement variable, the mean value is not included because it is eliminated in Equation (4). Sensor placement analysis based on SED described in this paper is using IES-VE model output data. Thermal environment parameter data at the height of $1.1 \mathrm{~m}, x$, and at sensor's position, $y$, are gained from IES-VE model output data simulated with scenario shown in Table 3. The analysis was conducted by observing SED's mean and standard deviation from all simulation scenarios and SED scenarios within the tolerance range. Each SED's mean and standard deviation would show the accuracy and consistency of sensor measurement results in an alternative position. Meanwhile, SED's scenarios within the tolerance range show the sensor's coverage level in an alternative position. Based on those three values, a sensor position with the best performance is selected, representing the indoor thermal environment at the height of $1.1 \mathrm{~m}$.

\section{Implementation and validation of sensor placement analysis result}

The sensor placement analysis results discussed in section 2.4 is then implemented into a real indoor environment. The output of the installed sensors is compared with the result of thermal condition measurement at the height of $1.1 \mathrm{~m}$ as a validation technique. Both data are taken at the same time.

\section{RESULTS AND DISCUSSION}

\section{CFD model for school area and indoor thermal environment}

Geometry models of the school area and indoor thermal environment are shown in Figure 5. Residual values indicate the quality of the CFD model's numerical results from the convergence test in Figure 6. The simulation result had reached convergence where there is no change, which means additional iteration does not change the quality with the residual value less than $10^{-2}$. It could be achieved through 6000, 1200, and 1000 iterations for each school area, R15 classroom, and R33/R40 classroom. The mass balance test shows that mass flow entering the system through an inlet, and the mass flow leaving through an outlet equals $0 \mathrm{~kg} / \mathrm{s}$.

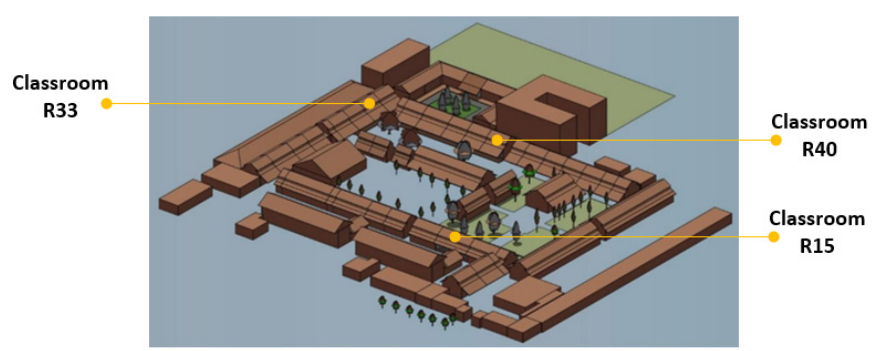

(a)

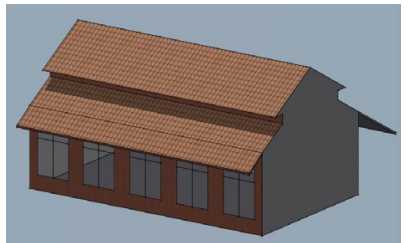

(b)

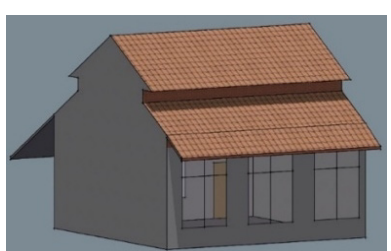

(c)
Figure 5: Geometry models of (a) school area, (b) R15 classroom, (c) R33 and R40 classrooms using IES-VE software

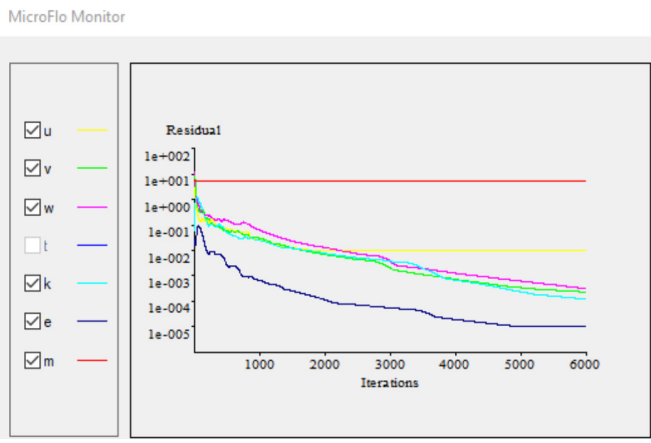

(a)

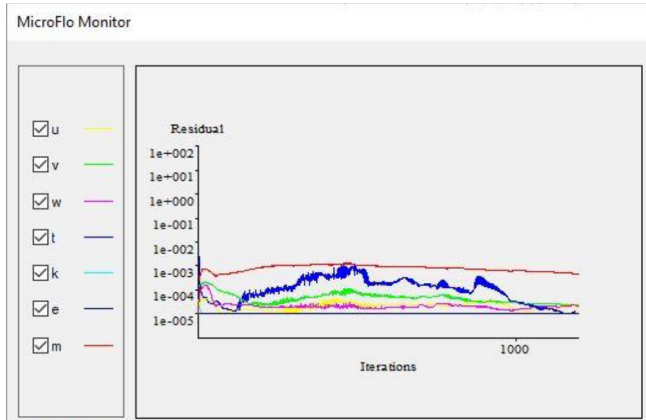

(b)

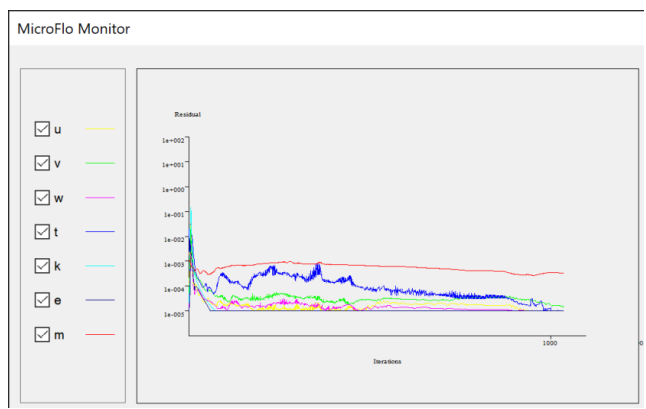

(c)

Figure 6: Residual values from model simulations of (a) school area, (b) R15 classroom, (c) R33 and R40 classrooms 
Table 4: RMSE between simulation and field measurement results

\begin{tabular}{|c|c|c|c|c|}
\hline $\begin{array}{c}\text { Thermal environment } \\
\text { parameter }\end{array}$ & School Area & R15 & R33 & R40 \\
\hline Envelope temperature $\left({ }^{\circ} \mathrm{C}\right)$ & 1.7 & - & - & - \\
\hline Air temperature $\left({ }^{\circ} \mathrm{C}\right)$ & - & 0.3 & 0.8 & 0.2 \\
\hline Relative humidity $(\%)$ & - & 0.6 & 3.5 & 3.0 \\
\hline Air/wind velocity $(\mathrm{m} / \mathrm{s})$ & 0.60 & 0.00 & 0.08 & 0.05 \\
\hline
\end{tabular}

Model validation is conducted by comparing model output values with field measurement values (Figure 7). RMSE values show the difference between these two values, as shown in Table 4. Several factors cause the difference between model output with field measurement, including the simulation weather data that is not quite the same with the weather during the field measurement, simplification of vegetation model in the school area, and a difference in occupants' activity on-site and simulation.

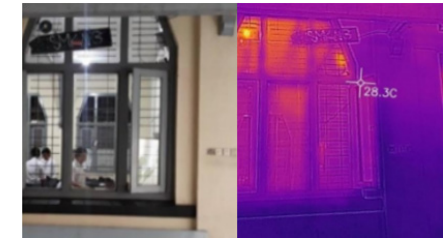

(a)

\section{Characterization of thermal environment through CFD model simulation results}

CFD model simulation results of the thermal environment in R15, R33, and R40 classrooms for all scenarios are shown in Figure 8. Thermal environment parameters include temperature, humidity, and air velocity at the height of $1.1 \mathrm{~m}$. The occupants will perceive thermal conditions at this height in a sitting position.

The indoor thermal environment is significantly influenced by the school area's thermal environment, including fabric, surface cover, dimension, structure of building composition, and human activities [26]. The dominant thermal environment parameters that affect the indoor thermal environment are irradiation flux on the building envelope and wind velocity on its surrounding area. Indoor heat gain is contributed by conduction on opaque surfaces due to the outdoor irradiation flux or radiation through oblique surfaces. Meanwhile, wind infiltration and exfiltration through small openings create changes

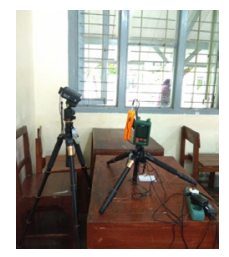

(b)

Figure 7: Model validation through building's wall temperature measurement using thermal camera (a) and indoor thermal environment parameter (b)
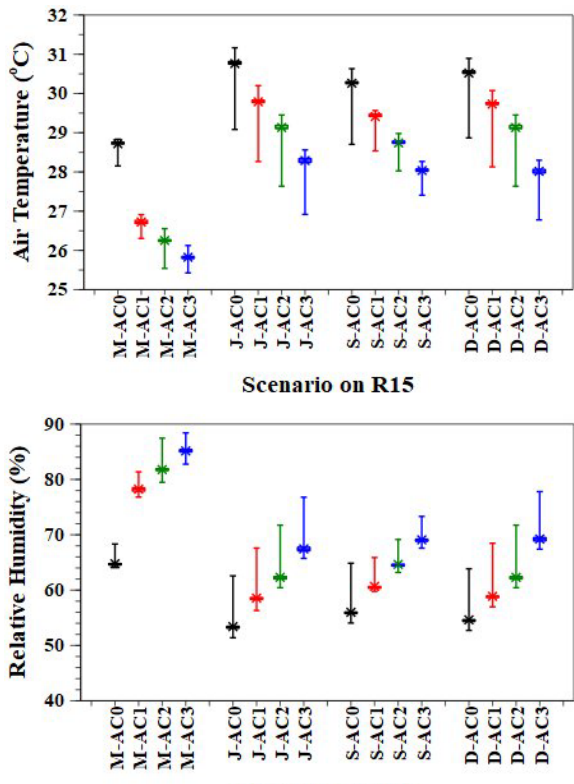

Scenario on R15

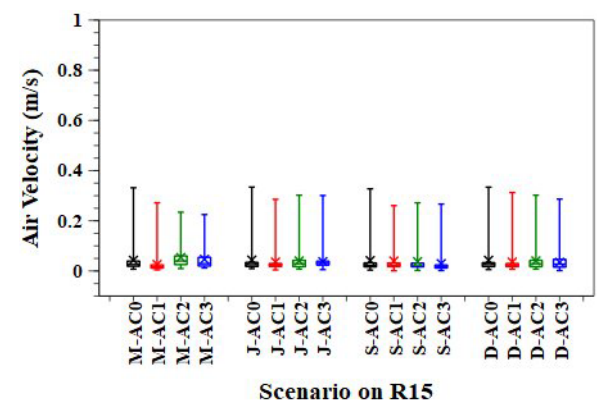

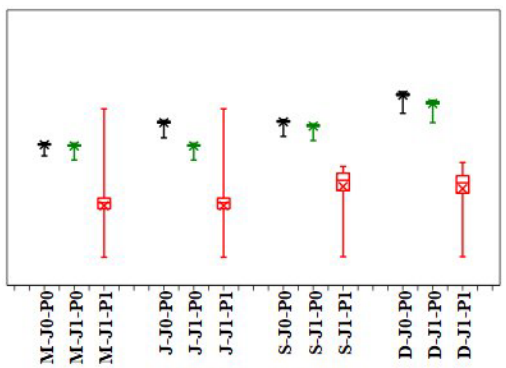

Scenario on $\mathbf{R 3 3}$
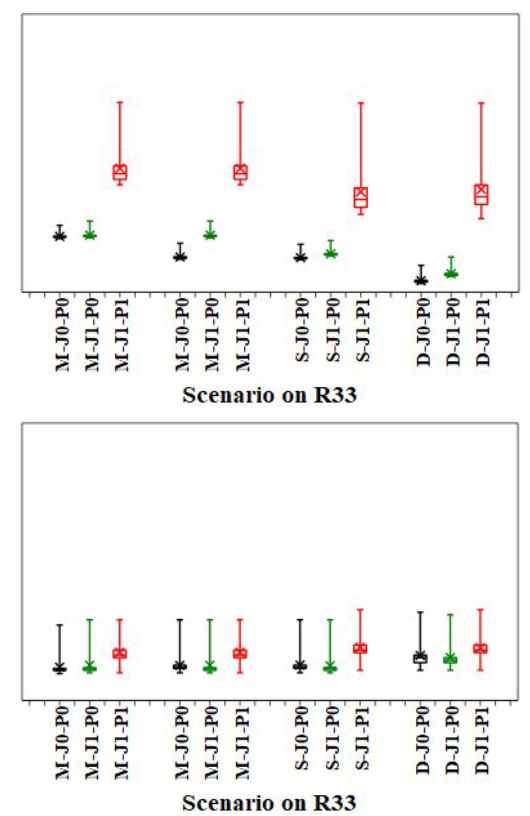
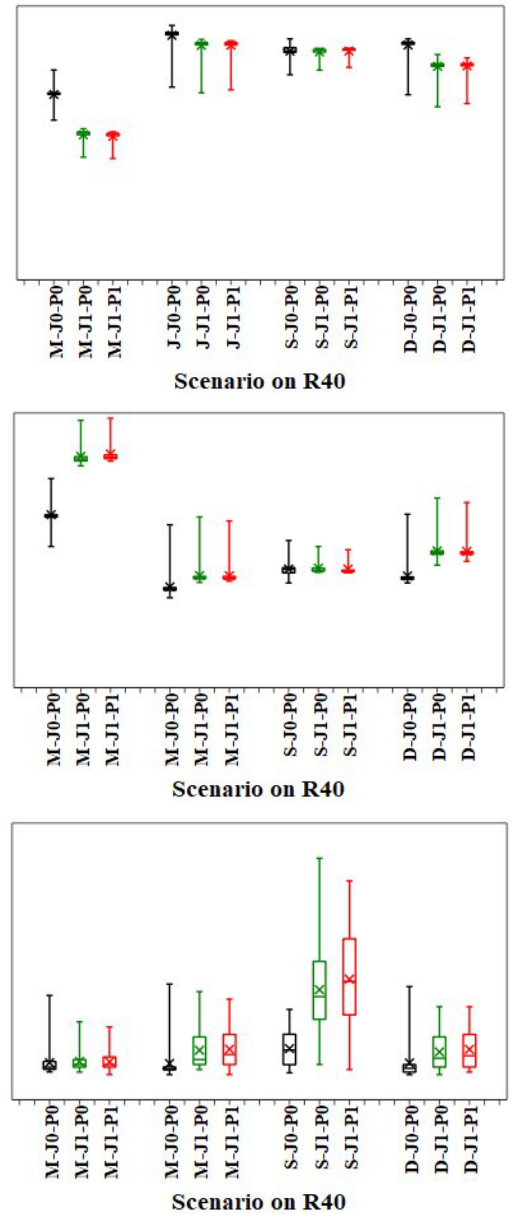

Figure 8: CFD model simulation result of thermal environment in $R 15, R 33$, and $R 40$ for all scenarios 
in the airflow rate. Both processes shall influence the room temperature, humidity, and air velocity.

Figure 9. shows the value of roof and wall irradiation flux in each classroom. The roof and wall irradiation flux in R15, $\mathrm{R} 33$, and R40 classrooms increases during the one-year climate cycle, with a maximum value of $310 \mathrm{~W} / \mathrm{m}^{2}$, and it happens in December. It is influenced by the sun's annual path and Yogyakarta city position, located at $6.97^{\circ} \mathrm{S}$ and $110.37^{\circ} \mathrm{S}$. R15, R33, and R40 classrooms use roofs and walls with the same materials but have different dimensions and structures due to other school areas' positions. A triangular prism-shaped roof, orientation, and shading caused by the structure's density will affect the irradiation flux amount on the classroom's roof and walls. The northsouth orientation of R15, without shading, and a relatively dense structure makes R15 has the highest roof and wall irradiation flux than two other rooms, with an average of $238 \mathrm{~W} / \mathrm{m}^{2}$ and $213 \mathrm{~W} / \mathrm{m}^{2}$, respectively, for the ceiling and walls. The roof and wall irradiation flux of R33 is the lowest among the two other rooms, with an average of 175 $\mathrm{W} / \mathrm{m}^{2}$ and $176 \mathrm{~W} / \mathrm{m}^{2}$ for roof and walls, respectively. The orientation in the east-west direction causes the roof side to get maximum solar radiation exposure alternately. The massive structure of R33 in the school area causes the wall to experience shading from the surrounding buildings.

Shading also occurs on the roof of R40 by the second-floor building from the north side. It is shown by the exposure time distribution in Figure 10, where the roof of R40 is not exposed to full solar radiation. With a north-south orientation, the irradiation flux value on the roof of R40 is not as high as $\mathrm{R} 15$, with an average of $176 \mathrm{~W} / \mathrm{m}^{2}$. The relatively dense structure causes the wall irradiation flux of R40 to be higher than R33, with an average of $186 \mathrm{~W} / \mathrm{m}^{2}$.

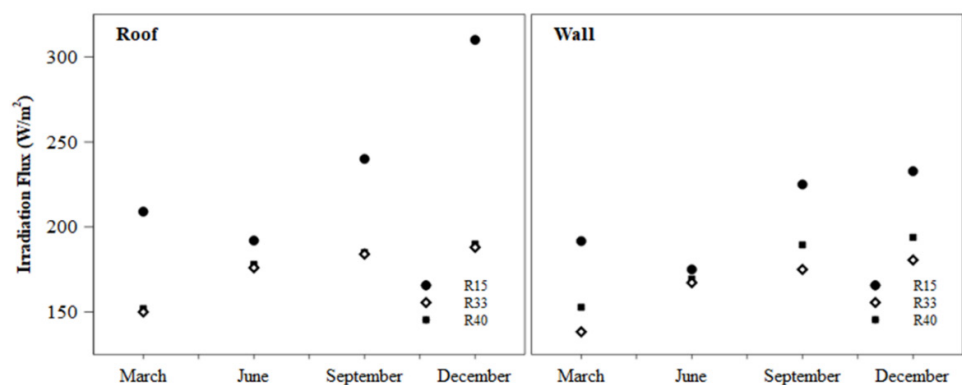

Figure 9: The average of irradiation flux on the roof and wall of R15, R33, and R40 classrooms

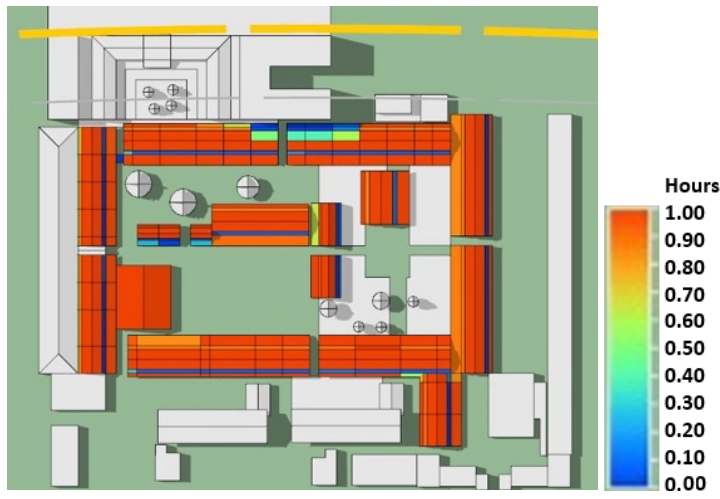

Figure 10: Exposure hour distribution that shows shading on R40's roof by the northern building
The roof and wall irradiation flux's value will affect the air temperature and humidity in the classroom, shown in Figure 8. The air temperature in R33 is the lowest compared to R15 and R40 due to the low irradiation flux value of R33's roof and walls. Meanwhile, although the wall and roof flux irradiation in R15 is the highest, the wider area causes the air temperature in the R15 classroom to be lower than in R40 classrooms. In the condition without $\mathrm{AC}$, all doors and windows are closed in all rooms and $\mathrm{R} 15$ 's $\mathrm{AC}$ is off, the air temperature in the classrooms reaches $30.7 \pm 0.2^{\circ} \mathrm{C}, 28.9 \pm 0.1^{\circ} \mathrm{C}$, and $30.9 \pm 0.3^{\circ} \mathrm{C}$, for $\mathrm{R} 15, \mathrm{R} 33$, and $\mathrm{R} 40$, respectively. The highest average air temperature is reached in June, during the dry season. Except for R33, due to heat stored from the adjacent workshop building (east of the R33), the highest average air temperature happens in December. The value of air humidity in the indoor environment is inversely proportional to the air temperature. The higher the air temperature at the same location and time, the lower the air humidity is [27]. The highest indoor air humidity values are achieved in March of $62.3 \% \pm 3.1 \%$ and $82.5 \% \pm 1.4 \%$ for R33 and R40, respectively, with the doors and windows open, and in March for R15, which reached 85.3\% $\pm 0.8 \%$ when all the air conditioners are on.

Figure 11 shows one of the dominant directions $\left(330^{\circ}\right)$ of the wind velocity distribution at the school area and the average initial rate of $2 \mathrm{~m} / \mathrm{s}$. Wind velocity in the school area will affect the indoor thermal condition for natural-

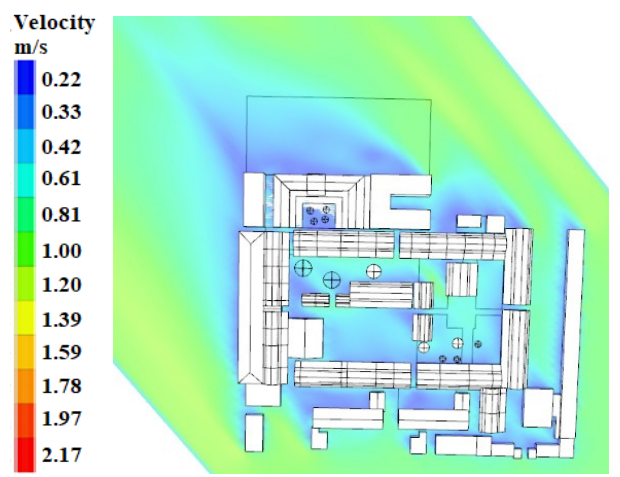

(a)
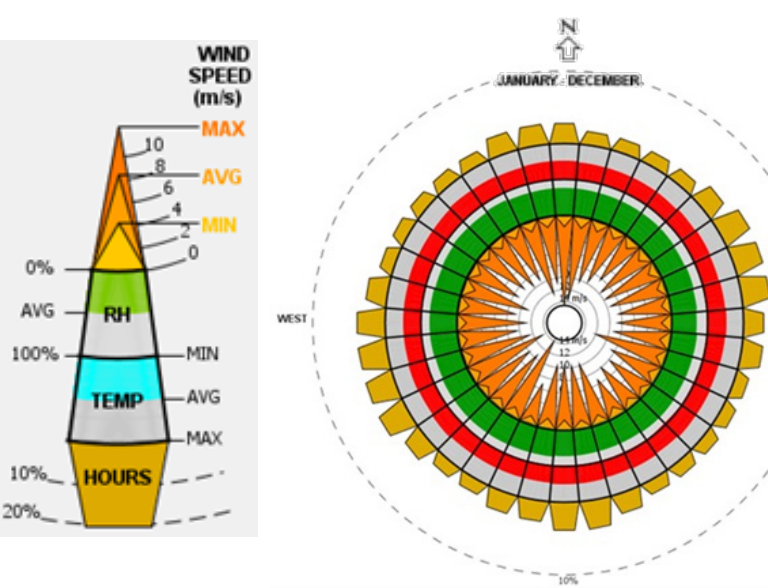

(b)

Figure 11: Distribution of school area's wind velocity in the direction of $320^{\circ}$ and average initial rate of $2 \mathrm{~m} / \mathrm{s}$ (a), according to Windrose diagram of SMKN 3 Yogyakarta (b) 


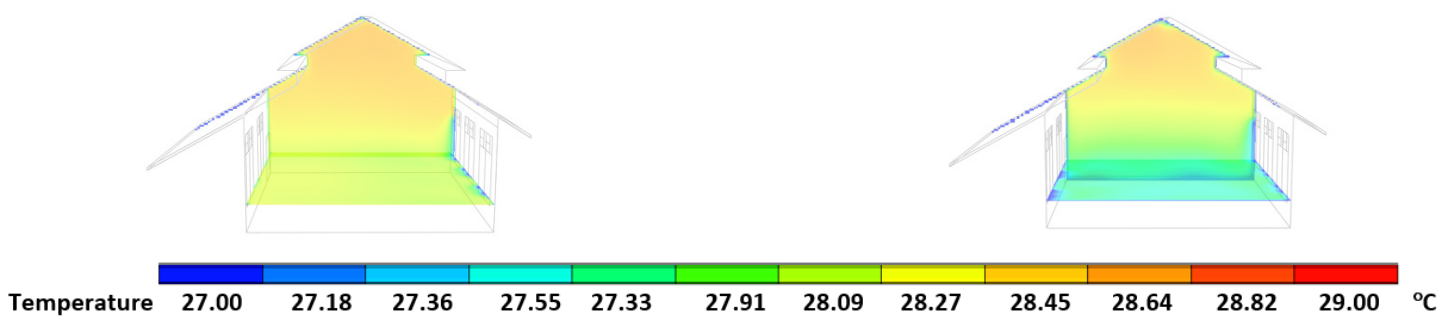

(a)

(b)

Figure 12: Distribution of air temperature in (a) R33 and (b) R40 with opened door and windows

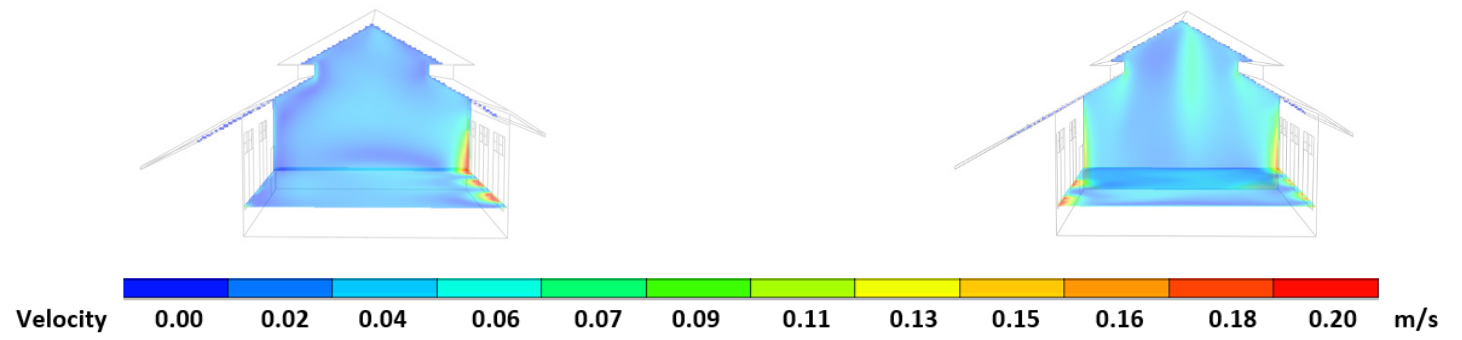

(a)

(b)

Figure 13: Distribution of air velocity in (a) R33 and (b) R40 with opened doors and windows

ly ventilated rooms (R33 and R40). Figure 8 shows that additional openings could decrease the indoor air temperature. Orientation and the number of openings would influence the indoor temperature and air velocity. R33 classroom has openings on the west and east walls. The west wall is attached to another building. The wind velocity in front of R33 at $1.5 \mathrm{~m}$ above the ground level is up to $0.5 \mathrm{~m} / \mathrm{s}$, while the indoor air velocity is $0.07 \pm 0.05$ $\mathrm{m} / \mathrm{s}$. Wind entering the east opening could not compensate for the heat or cold effect from the building attached on the west side. It creates temperature and humidity variations that are relatively high when the windows and doors of R33 are opened. A different condition happens in R40. Wind velocity at $1.5 \mathrm{~m}$ reaches $0.3 \mathrm{~m} / \mathrm{s}$ from the north and $0.4 \mathrm{~m} / \mathrm{s}$ from the south. The wind enters from both openings in north and south, causing relatively higher air velocity variations in R40 than in R33, which is $0.12 \pm 0.14 \mathrm{~m} / \mathrm{s}$ with a relatively even air temperature distribution. The distribution of temperature and air velocity in R33 and R40 is shown in Figures 12 and 13.

\section{Sensors placement analysis results}

Figure 14 shows an alternative position for installing sensors in the indoor environment. There are 20 alternative sensor positions in each room, with an equal distance of $1 \mathrm{~m}$ on the front (D) and rear (B) windowless walls. Determining alternative sensor positions should consider avoiding interference with occupants' activity, positions unreachable by occupants, and convenient installation.

The critical success of analysing sensor placement based on the indoor thermal environment characterization is how far the scenarios can represent all possible conditions in the real situation. Figure 15 shows the distribution of SED calculation results for all simulation scenarios in each alternative sensor position. In R15 and R40, a significant deviation occurs in the alternative sensor position 1 or 10 near the AC placement and the opening (see Figure 13), with values reaching $8.1 \pm 2.6$ and $6.7 \pm 1.4$ for R15 and R40, respectively. For the R33 classroom, the largest variation in SED value among other classrooms happens caused by variations in thermal conditions at $1.1 \mathrm{~m}$ due to heat stored from the workshop building attached to the east side of R33.
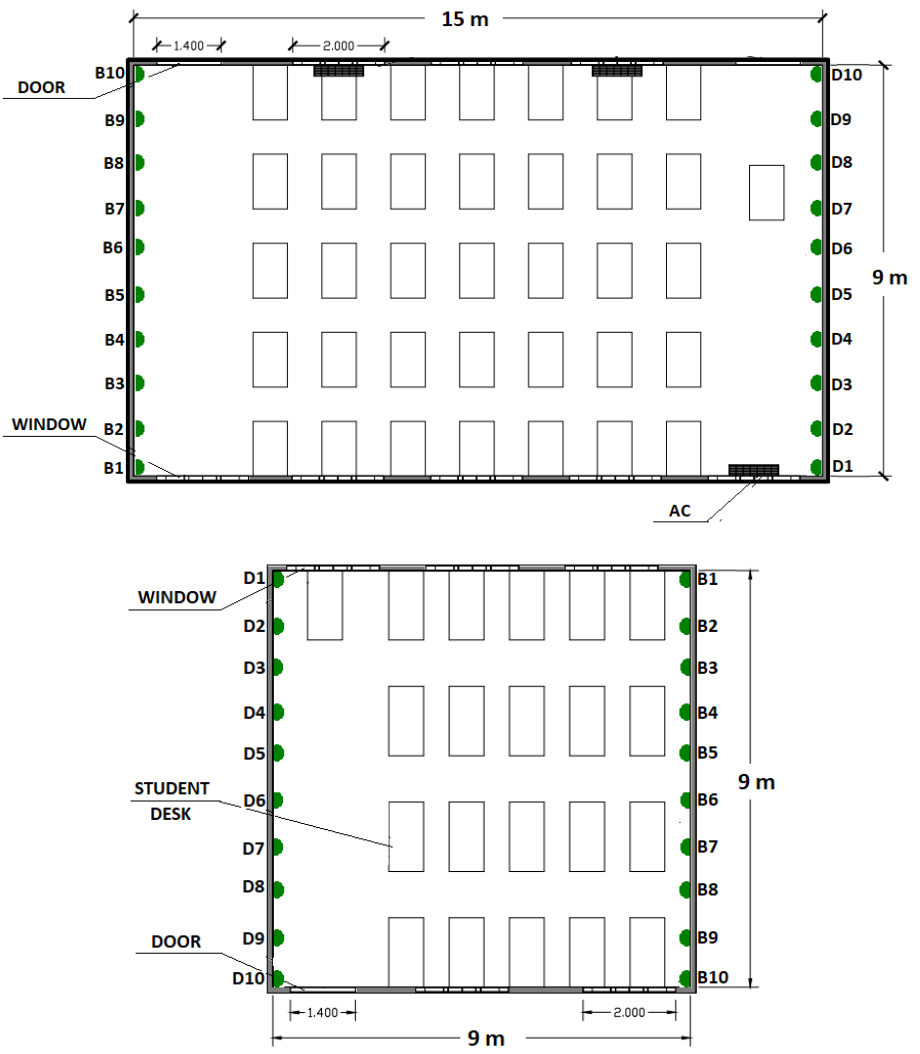

Figure 14: Alternative installed sensor positions in the indoor environment 

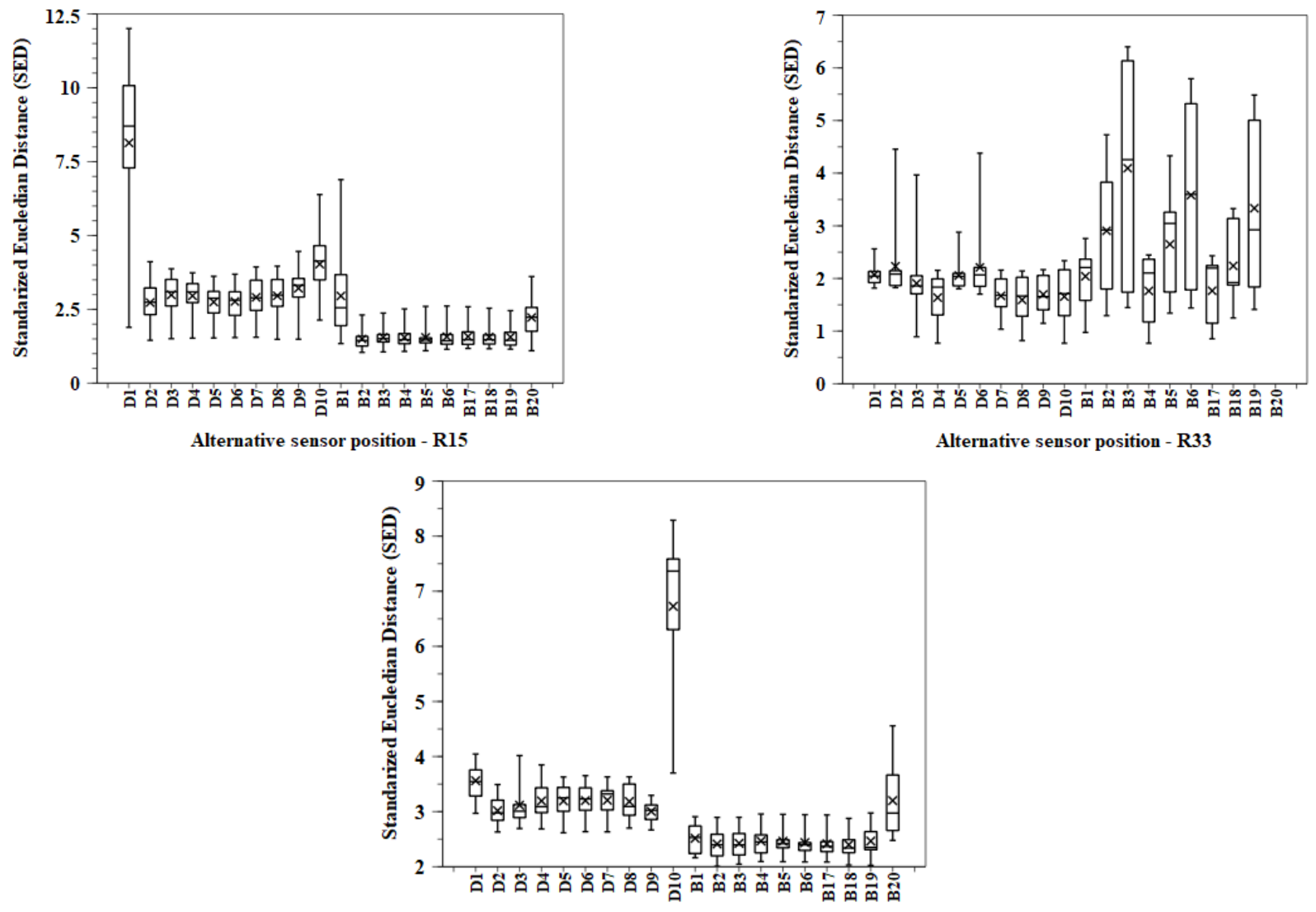

Alternative sensor position - R40

Figure 15: Distribution of SED calculation results data for all simulation scenarios in each alternative sensor position

Figure 16 shows SED's mean and SED's standard deviation and the percent (\%) coverage for all simulation scenarios. Percent (\%) coverage states the number of scenarios with the distribution of thermal environment

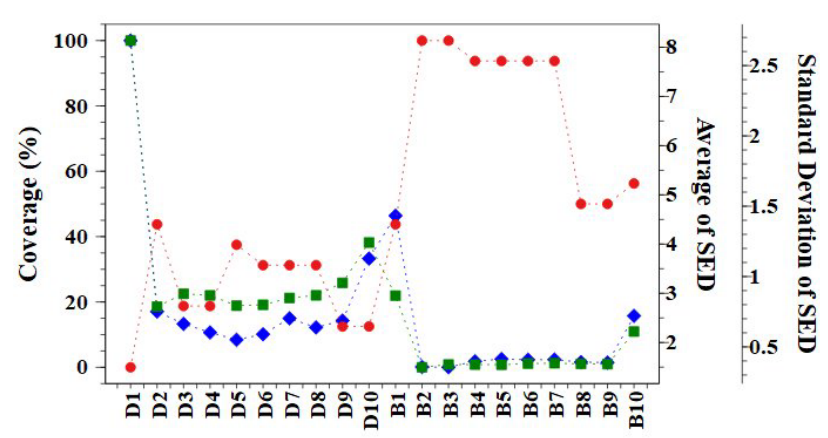

Alternative sensor position - R15 parameters represented by the sensor's value at an alternative position. The smallest mean and standard deviation of the SED indicate the accuracy and consistency of sensor measurements at an alternative position. In this
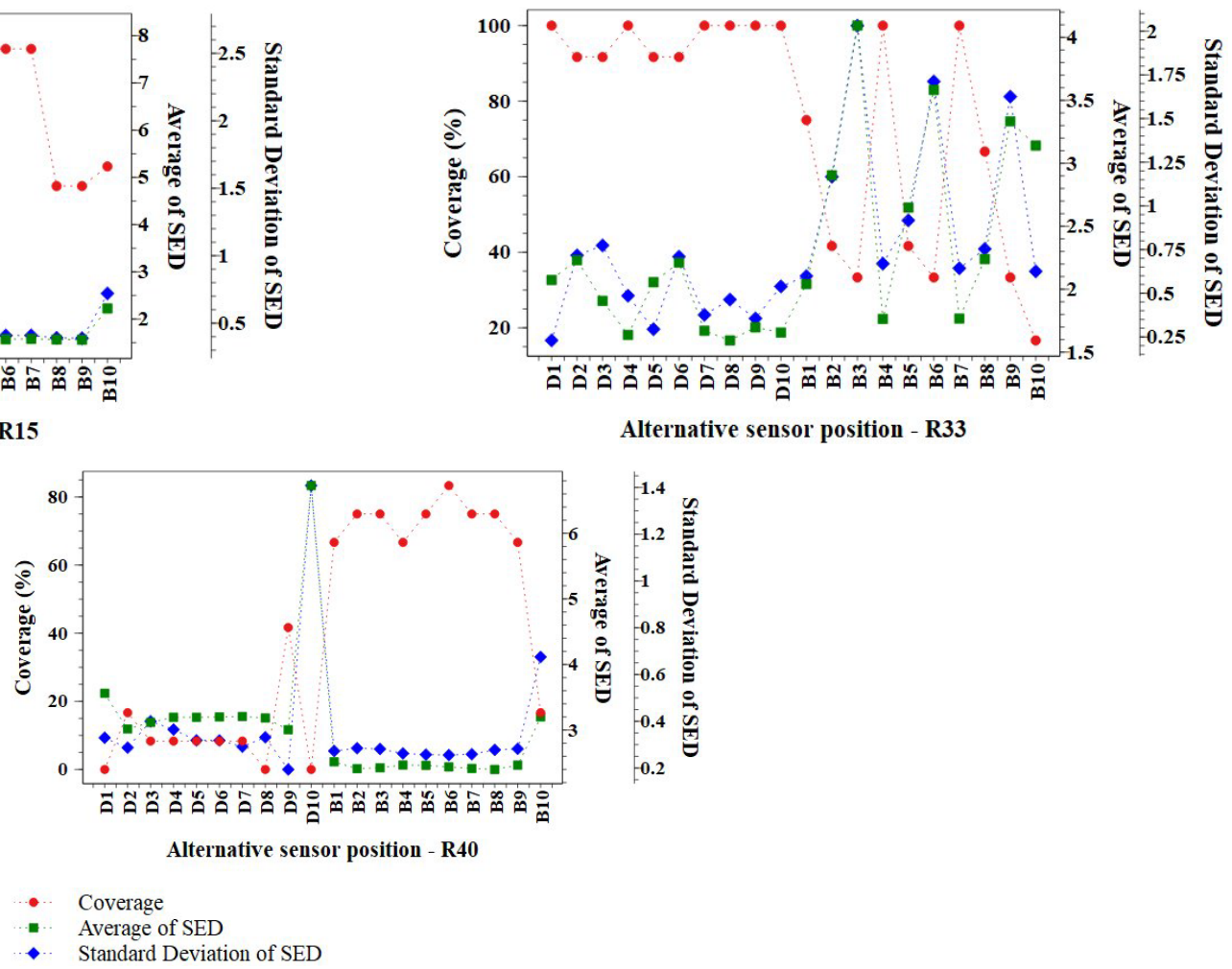

Figure 16: SED's mean and standard deviation for all simulation scenarios and \% coverage of an alternative sensor position 
Table 5: Measuring instrument specifications installed in the selected position

\begin{tabular}{|c|c|c|c|c|c|}
\hline Measured variables & Measuring instrument Name/Model & Model & Range & Accuracy & Resolution \\
\hline Air temperature & 1-Wire Parasite-Power Digital Thermometer & DS18B20 & $(-55)-100^{\circ} \mathrm{C}$ & $\pm 0.50{ }^{\circ} \mathrm{C}$ & $0.01^{\circ} \mathrm{C}$ \\
\hline Relative humidity & Humidity and Temperature Sensor IC & SHT20 & $0-100 \%$ & $\pm 3 \%$ & $0.7 \%$ \\
\hline Air/wind velocity & Hot Wire Anemometer & Lutron & $0-20 \mathrm{~m} / \mathrm{s}$ & $5 \%$ & $0.1 \mathrm{~m} / \mathrm{s}$ \\
\hline
\end{tabular}

paper, the SED tolerance value is set at 2.5. The thermal environment parameters distribution of a scenario can be represented by the sensor's data at an alternative position if it has an average SED value of less than 2.5 .

\section{Validation of sensor placement results}

Figure 17 shows the installed sensor in the R40 classroom based on the analysis results in 3.3. Similar sensor installations are also done for R15 and R33. The sensor specifications are shown in Table 5. Figure 18 shows the distribution of SED values between the thermal environment parameter from 5 locations of equal distance at $1.1 \mathrm{~m}$ from the ground level and the installed sensor's measurement result. Validation results of SED values are $2.5 \pm 0.3,2.2 \pm 0.6,2.0 \pm 1.1$, in R15, R33, and R40, respectively. In general, these results can be said to meet the design demands with an average SED of less than 2.5. However, large variations occur in the test results in naturally ventilated classrooms, R33 and R40. If we look at the SED graph of the test results in Figure 18, this considerable SED variation is caused by the large SED variations in the air velocity dimensions. SED variations in the air velocity dimension arise because, during the test, the classroom's door and windows are opened. There is a difference in the air velocity value detected by the measuring instrument at the test point position with

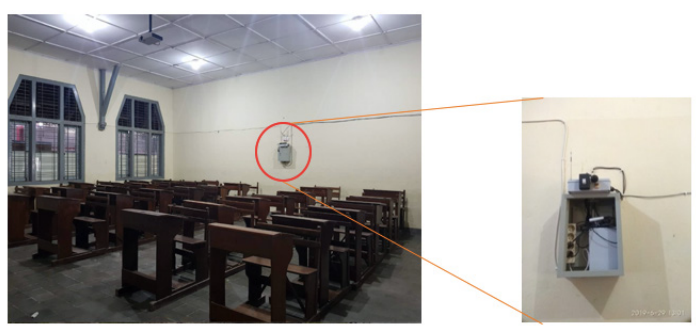

Figure 17: The installed sensor in the selected position in the $R 40$ classroom the installed sensor value. This difference is more visible because the measuring instrument's resolution is 0.1 $\mathrm{m} / \mathrm{s}$. In contrast, according to the simulation results, the difference can occur with a value smaller than the measuring instrument's resolution.

\section{CONCLUSIONS}

Based on the discussion, it can be concluded that,

1. Models of indoor and school area environments succeed in IES-VE software with a residual value of less than $10^{-2}$. Model validation using field measurement resulted in a maximum RMSE value of $0.8^{\circ} \mathrm{C}, 3.5 \%$, and $0.08 \mathrm{~m} / \mathrm{s}$ for indoor temperature, relative humidity, and air velocity variables.

2. The indoor environment position in the school area significantly influences the indoor thermal environment. With the same materials, north-south orientation and no shading from surrounding building cause the roof and wall irradiation flux of R15 classroom is higher than R33 and R40, with an average of $238 \mathrm{~W} / \mathrm{m}^{2}$ and $213 \mathrm{~W} / \mathrm{m}^{2}$ respectively for the ceiling and walls. The heat stored in the building attached to the R33 classroom makes the indoor air temperature not fluctuating throughout the year, and reaching $28.9 \pm 0.1^{\circ} \mathrm{C}$. Wind with a velocity of $0.4 \mathrm{~m} / \mathrm{s}$ enters from both sides of openings in R40 classroom, which have a non-solid structure, causing air velocity variation inside the room with a value of $0.12 \pm 0.14 \mathrm{~m} / \mathrm{s}$ and an even air temperature distribution.

3. Sensor positions with the best performance in representing the indoor thermal environment at the height of $1.1 \mathrm{~m}$ are $\mathrm{B} 5$ for R15, D4 for R33, and B6 for R40. These positions are selected by considering the occupant's activity, safety, installation convenience, and SED analysis, showing accuracy, consistency, and $\%$ coverage of a sensor position. Validation
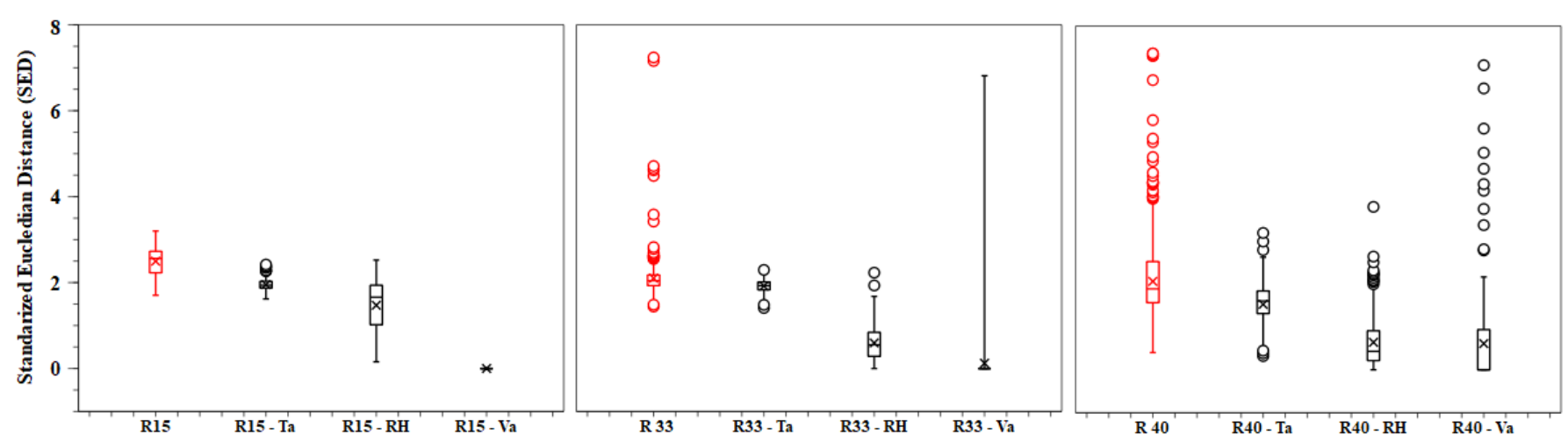

Figure 18: Distribution of SED value from sensor measurement results in the selected positions and SED for each dimension component, including temperature $\left(t_{a}\right)$, relative humidity $(R H)$, and air velocity $\left(v_{a}\right)$ 
results show that sensors in the selected positions could detect thermal variables at the height of 1.1 $\mathrm{m}$ with SED validation values of $2.5 \pm 0.3,2.2 \pm 0.6$, 2.0 1 1.1, for R15, R33, and R40.

This paper focuses on the method in selecting the optimal sensor positions to obtain the most accurate data to represent the thermal environment characteristics of the occupant activity area. The sensors' accuracy influences the overall performance of the BMS in its function as a system to monitor indoor thermal comfort in an energy efficient building. Data accuracy also depends on the sensor's specification, which includes the data resolution during the sensor readings. Hence, the resolution should match with the indoor thermal environment characteristics produced from the CFD simulations. However, this issue is still considered as the limitation of this research and must be included in future work.

\section{ACKNOWLEDGEMENT}

This research is supported by the Indonesian Ministry of Higher Education and Technology through a funding scheme PTUPT No. 2925/UN1.DITLIT/D IT-LIT/PT/2020 and Universitas Gadjah Mada Indonesia. The author would also like to thank Integrated Smart and Green Building (Insgreeb) Research Group and PT. Amakusa for their support throughout the developing process and testing of the system in this research.

\section{DATA AVAILABILITY}

The indoor thermal environment data used to support this study's findings have not been made available due to the agreement with the research partner remaining in process.

\section{CONFLICTS OF INTEREST}

The author(s) declare(s) that there is no conflict of interest regarding the publication of this paper.

\section{REFERENCES}

1. H. Batih and C. Sorapipatana. (2016). Characteristics of urban households' electrical energy consumption in Indonesia and its saving potentials. Renew. Sustain. Energy Rev., vol. 57, pp. 1160-1173, DOI: 0.1016/j. rser.2015.12.132.

2. ASHRAE Standard 55. (2010). Thermal environmental conditions for human occupancy. American Society of Heating Refrigerating and Air-Conditioning Engineers, Inc, Atlanta.

3. P. Fanger. (1970). Thermal comfort: Analysis and Applications in Environmental Engineering. Danish Technical Press, Copenhagen, Denmark.

4. K. Parsons. (2003). Human Thermal Environments: The Effects of Hot, Moderate, and Cold Environments on Human Health, Comfort and Performance, Second Edition. Taylor \& Francis Group, Boca Raton.
5. M. J. Varas-Muriel, R. Fort, M. I. Martínez-Garrido, A. Zornoza-Indart, and P. López-Arce. (2014). Fluctuations in the indoor environment in Spanish rural churches and their effects on heritage conservation: Hygro-thermal and $\mathrm{CO} 2$ conditions monitoring. Build. Environ., vol. 82, pp. 97-109, DOI: 10.1016/j.buildenv.2014.08.010.

6. W. Rattanongphisat, T. Prachaona, A. Harfield, K. Sato, and O. Hanaoka. (2017). Indoor Climate Data Analysis Based a Monitoring Platform for Thermal Comfort Evaluation and Energy Conservation. Energy Procedia, vol. 138, pp. 211-216, DOI: 10.1016/j.egypro.2017.10.152.

7. M. W. Ahmad, M. Mourshed, D. Mundow, M. Sisinni, and Y. Rezgui. (2016). Building energy metering and environmental monitoring - A state-of-the-art review and directions for future research. Energy Build., vol. 120, pp. 85-102, DOI: 0.1016/j.enbuild.2016.03.059.

8. T. Seabrook. (2016). Optimal Placement Strategies of Minimum Effective Sensors for Application in Smart Buildings. Energy and Buildings, vol 158, pp. 12061225, DOI: 10.1016/j.enbuild.2017.10.074.

9. H. Hayat et al. (2019). The state-of-the-art of sensors and environmental monitoring technologies in buildings. Sensors (Switzerland), vol. 19, no. 17, DOI: 10.3390/s19173648.

10. D. G. Eliades, M. P. Michaelides, C. G. Panayiotou, and M. M. Polycarpou. (2013). Security-oriented sensor placement in intelligent buildings. Build. Environ., vol. 63, pp. 114-121, DOI: 10.1016/j.buildenv.2013.02.006

11. H. Sharma, U. Vaidya, and B. Ganapathysubramanian. (2019). A transfer operator methodology for optimal sensor placement accounting for uncertainty. Build. Environ., vol. 155, no. March, pp. 334-349, DOI: 10.1016/j.buildenv.2019.03.054.

12. J. Waeytens and S. Sadr. (2018). Computer-aided placement of air quality sensors using adjoint framework and sensor features to localize indoor source emission. Build. Environ., vol. 144, no. August, pp. 184-193, DOI: 10.1016/j.buildenv.2018.08.012.

13. R. J. Yanti, Faridah, I. W. Mustika, D. D. Ariananda, and S. S. Utami. (2020). Analysis of Gaussian process to predict thermal sensor placement for controlling energy consumption on the educational building. AIP Conference Proceedings, vol. 2223, DOI: 10.1063/5.0000923.

14. S. Yeon Lee, I. bok Lee, U. Hyeon Yeo, R. woo Kim, and J. Gyu Kim. (2019). Optimal sensor placement for monitoring and controlling greenhouse internal environments. Biosyst. Eng., vol. 188, pp. 190-206, DOI: 10.1016/j.biosystemseng.2019.10.005. 
15. D. Yoganathan, S. Kondepudi, B. Kalluri, and S. Manthapuri. (2018). Optimal sensor placement strategy for office buildings using clustering algorithms. Energy Build., vol. 158, pp. 1206-1225.

16. P. Erickson, M. Cline, N. Tirpankar, and T. Henderson. (2015). Gaussian processes for multi-sensor environmental monitoring. IEEE Int. Conf. Multisens. Fusion Integr. Intell. Syst., vol. 2015-October, pp. 208-213, DOI: 10.1109/MFI.2015.7295810.

17. M. Al-Kuwari, A. Ramadan, Y. Ismael, L. Al-Sughair, A. Gastli, and M. Benammar. (2018). Smart-home automation using loT-based sensing and monitoring platform. Proc. - 2018 IEEE 12th Int. Conf. Compat. Power Electron. Power Eng. CPE-POWERENG 2018, pp. 1-6, DOI: 10.1109/CPE.2018.8372548.

18. P. Zhou, G. Huang, L. Zhang, and K. F. Tsang. (2015). Wireless sensor network based monitoring system for a large-scale indoor space: Data process and supply air allocation optimization. Energy Build., vol. 103, pp. 365-374, DOI: 10.1016/j.enbuild.2015.06.042.

19. Y. Jin, Y. Xiong, L. Wang, Y. X. Liu, and Y. Zhang. (2018). Eco-feedback for thermal comfort and cost efficiency in a nearly zero-energy residence in Guilin, China. Energy Build., vol. 173, pp. 1-10, DOI: 10.1016/j.enbuild.2018.04.025.

20. M. Greenacre and R. Primicerio. (2013). Multivariate Analysis of Ecological Data, Rubes Edit. Spain: Fundación BBVA.
21. R. Geiger, H. Aron, and P. Todhunter. (1961). The Climate Near the Ground, 5th ed. Harvard University Press, Cambridge, Mass.

22. A. Al-janabi, M. Kavgic, A. Mohammadzadeh, and A. Azzouz. (2019). Comparison of EnergyPlus and IES to model a complex university building using three scenarios: Free-floating, ideal air load system, and detailed. J. Build. Eng., vol. 22, no. September 2018, pp. 262-280, DOI: 10.1016/j.jobe.2018.12.022.

23. D. B. Crawley, J. W. Hand, M. Kummert, and B. T. Griffith. (2008). Contrasting the capabilities of building energy performance simulation programs. Build. Environ., vol. 43, no. 4, pp. 661-673, DOI: 0.1016/j. buildenv.2006.10.027

24. Jamal M Saleh. (2002). Fluid flow handbook. McGraw-Hill, New York.

25. Hugo Hens. (2017). Building Physics Heat, Air, and Moisture: Fundamentals and Engineering Methods with Examples and Exercices, Third.Wilhelm Ernst \& Sohn, Germany.

26. T. R. Oke, G. Mills, A. Christen, and J. A. Voogt. (2017). Urban Climates. Cambridge University Press, UK.

27. I. Kurniawan, Faridah, and S. S. Utami. (2020). Characterizing of climate chamber thermal environment using the CFD simulation method using IES VE. AIP Conference Proceedings, vol. 2223, DOI: 10.1063/5.0000924. 